\title{
Outcomes of early cholecystectomy (within 7 days of admission) for acute cholecystitis according to diagnosis and severity grading by Tokyo 2013 Guideline
}

\author{
Ismail Sert ${ }^{1}$, Fuat İpekci², Ömer Engin ${ }^{3}$, Muharrem Karaoğlan², Özhan Çetindağ ${ }^{2}$
}

\section{ABSTRACT}

Cite this paper as:

Sert I, İpekci F, Engin 0 , Karaoğlan M, Çetindağ

0̈. Outcomes of early

cholecystectomy (within 7

days of admission) for acute

cholecystitis according to

diagnosis and severity grading

by Tokyo 2013 Guideline. Turk

J Surg 2017; 33(2): 80-86

'Clinic of General Surgery and Transplantation, Tepecik Training and Research Hospital, İzmir, Turkey

${ }^{2}$ Clinic of General Surgery, Tepecik Training and Research Hospital, İzmir, Turkey ${ }^{3}$ Clinic of General Surgery, Buca Seyfi Demirsoy State Hospital, İzmir, Turkey

This study was presented at the $20^{\text {th }}$ National Congress of Surgery, 13-17 April 2016, Antalya, Turkey.

Address for Correspondence İsmail Sert

e-mail:drismailsertege@yahoo.com

Received: 30.07 .2015

Accepted: 01.11.2015

(C) Copyright 2017 by Turkish Surgical Association
Objective: The timing of early cholecystectomy in acute cholecystitis is still controversial, and data regarding the use of Tokyo 2013 guideline for diagnosis and severity grading in Acute Cholecystitis is limited. The aim of this study was to evaluate the clinical and pathologic outcomes of early cholecystectomy after $72 \mathrm{hr}$ and within seven days of index admission according to Tokyo 2013 guideline for diagnosis and severity grading of Acute cholecystitis (in patients with Acute cholecystitis.

Material and Methods: Medical charts of 172 patients who underwent early cholecystectomy after $72 \mathrm{hr}$ and within 7 days of index admission with a diagnosis of Acute cholecystitis between Aug 2009 and Apr 2014 were retrospectively analyzed. Patients were classified according Tokyo 2013 guideline criteria.

Results: The median age of the study group was $52 \mathrm{yr}$. The rates of open and laparoscopic cholecystectomies was $53.5 \%$ and $33.1 \%$, respectively. Conversion to open cholecystectomy was performed in 19 patients (13.4 \%). The median length of hospital stay was 7 days. Eighty-four patients (59.2\%) met the criteria for a definite diagnosis of Acute cholecystitis according to Tokyo 2013 guideline. Longer postoperative and total length of hospital stay was determined in patients with a definite diagnosis.

Conclusion: Increased severity grading is correlated with longer pre- and post-operative hospital stay. Early cholecystectomy in Acute cholecystitis performed by experienced surgeons after $72 \mathrm{hr}$ of admission and within 7 days maybe a feasible and safe procedure.

Keywords: Acute cholecystitis, diagnosis, early cholecystectomy, Tokyo 2013 guideline, severity grading

\section{INTRODUCTION}

Gallstones represent a common health problem (6.5-15\%) in the Western population (1, 2). Approximately $1-4 \%$ of these patients develop complications (mainly acute cholecystitis (AC)) related to the gallbladder stone every year (3). Although the safety and feasibility of early cholecystectomy in the treatment of acute cholecystitis have been demonstrated, there is still no current consensus on the timing of early cholecystectomy (4-9). According to Tokyo 2013 guidelines (TG 13) for diagnosis and severity grading of acute cholecystitis (TG 13), early laparoscopic cholecystectomy for acute cholecystitis should be performed within $72 \mathrm{hrs}$. from the onset of symptoms (10). In daily practice, patients with acute cholecystitis who present $72 \mathrm{hr}$ later than the onset of symptoms are generally referred to interval cholecystectomy after medical treatment.

Interval cholecystectomy has some disadvantages including the need for emergency surgery due to failure of medical treatment, re-hospitalization due to symptom recurrence, a difficult and unsafe interval cholecystectomy because of fibrosis, an increase in health-expenditure due to re-hospitalization, and the possibility of being lost to follow-up (11). Owing to these above mentioned factors, the definition of $72 \mathrm{hr}$ for early laparoscopic cholecystectomy has recently been changed. The early period is now defined as 24 h-7 days, based on multicenter randomized controlled studies $(5,12)$.

Although, the timing of early laparoscopic cholecystectomy is still controversial, early laparoscopic cholecystectomy gains acceptance day by day. Although several guidelines suggest ELC in acute cholecystitis (10-13), the rate of early cholecystectomy still remains low i.e. 15-40\% (14-16).

A standard approach on the definition and severity assessment of acute cholecystitis is not present. TG 13 describes the diagnosis, severity grading and treatment strategies for acute cholecystitis. By the help of TG 13, the diagnostic sensitivity of acute cholecystitis increased while the rate of false positivity decreased. Moreover, the criteria defined for severity assessment are adopted to daily clinical practice (17). 
The aim of the present study was to evaluate the clinical and pathologic outcomes of early cholecystectomy after $72 \mathrm{hr}$ and within seven days of index admission in patients with acute cholecystitis according to TG 13 for the diagnosis and severity grading of acute cholecystitis.

\section{MATERIAL AND METHODS}

Medical charts of 172 patients who underwent early cholecystectomy after $72 \mathrm{hr}$ and within 7 days of index admission with a diagnosis of acute cholecystitis between Aug 2009 and Apr 2014 were retrospectively analyzed. A total of 142 patients that met the inclusion criteria were enrolled. Patient demographic data (age, gender, comorbidities, etc.), time to operation, antibiotic therapy, ASA score, surgical procedure, postoperative complications, length of hospital stay were documented. This study has been approved by the local ethic committee of Tepecik Training and Research hospital. Patient informed consent was not obtained due to retrospective nature of the study.

Patients under 18 years old, those with acute pancreatitis ( $\mathrm{n}$ : $5)$, acute cholangitis ( $n: 1)$, acalculous cholecystitis, or choledocholithiasis (n: 7), those who have been conservatively treated (n: 5), not underwent cholecystectomy within 7 days of index admission (n: 8), and with a missing final pathology report (n: 4) were excluded from the study. All patients in the study underwent early cholecystectomy between 3-7 days of index admission.

Diagnosis of acute cholecystitis was based on patients local examination (Murphy's sign, pain, tenderness or mass in right upper quadrant), systemic (fever, high CRP levels or abnormal white blood cell count), and imaging (gallbladder stones, thickened gallbladder wall ( $>4 \mathrm{~mm}$ ), pericholecystic fluid, sonographic Murphy's sign) findings according to TG 13 (18). Patients were classified as those with a suspected diagnosis (having positive local and systemic findings) or with a definite diagnosis (having positive local, systemic and imaging findings) groups. Patients were then clinically graded for severity as mild, moderate or severe according to severity grading of TG 13 (18). According to final histology reports, patients with acute cholecystitis were also divided into four groups as acute, phlegmonous, gangrenous, and chronic cholecystitis.

Surgical procedures were simply categorized as open, laparoscopic and conversion from laparoscopic to open cholecystectomy. Laparoscopic cholecystectomy was performed with standard 4 trocar operative technique. Planned open cholecystectomy was performed with a right subcostal incision. In case of presence of distended gallbladder, it was decompressed by using a needle. In the presence of a phlegmon, blunt dissection was performed and the cleavage composed by omentum and surrounding tissues was followed. Dissection was performed by using monopolar cautery or sealing devices. Cholecystectomy was not performed without identification of all structures within Callot's triangle. All operations were performed by experienced surgeons. A standard objective criterion was not used to convert from laparoscopy to open cholecystectomy. Decision of conversion to open cholecystectomy was based on surgeon preference, history of previous abdominal surgery, clinical and laboratory findings, and disease severity. A subhepatic drain was almost always inserted. The drain was generally removed at postoperative day 1 . None of the patients had percutaneous cholecystectomy or partial cholecystectomy. The timing of the operation was determined according to clinical and laboratory response to medical treatment, and feasibility of the operating theater. If needed, magnetic resonance cholangiography was obtained. Intraoperative cholangiography was not performed.

All patients received intravenous antibiotic treatment on admission. Antibiotherapy was continued for $24 \mathrm{hrs}$. after surgery. Oral intake was resumed after one or two days according to clinical and laboratory findings. During this period, parenteral fluid support was ensured. Perioperative local and systemic complications were recorded.

\section{Statistical Analysis}

All statistical analysis was performed with the Statistical Package for the Social Sciences for Windows, version 15.0 software program (SPSS Inc.; Chicago, IL, USA). Continuous variables are presented as means $\pm S D$, and categorical variables as frequencies and percentages. Continuous variables were compared using Student-t test or Wilcoxon test when appropriate. Chisquare or fisher exact test was performed for comparison of differences in categorical variables. $p<0.05$ was considered statistically significant. Risk factors for conversion and factors related to pre-operative, post-operative and total length of hospital stay were evaluated in a univariate model, and statistically significant parameters were then evaluated in a multivariate analysis to determine the independent factors. Odds ratio and 95\% confidence intervals (Cl 95\%) were calculated using a logistic regression model.

\section{RESULTS}

The median age of the patients was $52 \mathrm{yr}$. Ninety patients $(63.6 \%)$ were female. The rate of patients older than 65 years was $19.7 \%$ ( $\mathrm{n}: 28)$. The rate of open and laparoscopic cholecystectomy was $53.5 \%$ and $33.1 \%$, respectively. Conversion to open cholecystectomy was performed in 19 patients (13.4\%). The total rate of local and systemic complications was $7 \%$ (n: 10). The median length of hospital stay was 7 days. Demographic data and clinical characteristics of the patients are shown in Table 1.

Eighty-four patients (59.2\%) met the criteria for a definite diagnosis of AC according to Tokyo guideline 2013. All patients with a suspected diagnosis had grade 1 disease. Distribution of the patients with definite diagnosis according to disease severity was as follows; $57.1 \%$ grade $1,36.9 \%$ grade 2 , and $6 \%$ grade 3. Distribution and characteristics of the patients according to suspected and definite acute cholecystitis diagnosis are shown in Table 2.

Based on clinical severity; $74.6 \%$ of the patients had mild, $21.8 \%$ moderate, and $3.5 \%$ had severe disease. The rate of male patients within moderate and severe disease group was significantly higher. All patients with a suspected diagnosis had grade 1 disease. The rate of patients with a definite diagnosis in grade 2 and grade 3 groups were $37 \%$ and $6 \%$, respectively. Patient characteristics and distribution according to Tokyo severity grading are demonstrated in Table 3 in details. 
Sert et al.

Early cholecystectomy for acute cholecystitis

Table 1. Demographic data and clinical characteristics of the patients

\begin{tabular}{|cccccc|} 
& \multicolumn{3}{c}{ Percentage } & & Min- \\
& $\mathbf{n}$ & $\%$ & Mean \pm sd & Median & $\max$ \\
\hline Age & 142 & & $51 \pm 15$ & 52 & $22-78$ \\
\hline
\end{tabular}

\section{Age group}

\begin{tabular}{lcc|}
$\leq 65$ yrs. & 114 & 80.3 \\
$>65$ yrs. & 28 & 19.7 \\
\hline Gender & & \\
Female & 90 & 63.4 \\
Male & 52 & 36.6 \\
\hline
\end{tabular}

ASA

$\begin{array}{ccc}1 & 32 & 22.5 \\ 2 & 103 & 72.5 \\ 3 & 3 & 4.9\end{array}$

\section{Comorbidities}

Chronic Obstructive

$\begin{array}{lll}\text { lung disease } & 3 & 2.1\end{array}$

Congestive heart failure $\quad 3 \quad 2.1$

Diabetes mellitus $\quad 6 \quad 4.2$

$\begin{array}{lll}\text { Hypertension } & 4 & 2.8\end{array}$

End stage renal Failure $\quad 1 \quad 0.7$

$\begin{array}{lll}\text { None } & 125 \quad 88\end{array}$

\begin{tabular}{|lcccc|}
\hline Pre-op hospital stay & 142 & $4.7 \pm 1.4$ & 4.0 & $2-7$ \\
\hline Post-op hospital stay & 142 & $3.3 \pm 1.8$ & 3.0 & $1-12$ \\
\hline Total hospital stay & 142 & $7.9 \pm 2.6$ & 7.0 & $4-17$ \\
\hline Time of operation & 142 & $4.6 \pm 1.4$ & 2.0 & 7.0 \\
\hline
\end{tabular}

Diagnosis

$\begin{array}{lll}\text { Suspected } & 58 \quad 40.8\end{array}$

Definite $\quad 84 \quad 59.2$

$\begin{array}{lcc}\text { Grade (according to TG 13) } & & \\ \text { Grade } 1 & 106 & 74.6 \\ \text { Grade 2 } & 31 & 21.8 \\ \text { Grade 3 } & 5 & 3.5\end{array}$

\section{Operation}

\begin{tabular}{lcc|} 
Laparoscopic & 47 & 33.1 \\
Open & 76 & 53.5 \\
Conversion & 19 & 13.4 \\
\hline Pathologic diagnosis & & \\
Acute cholecystitis & 42 & 29.6 \\
Phlegmonous Cholecystitis & 6 & 4.2 \\
Gangrenous Cholecystitis & 10 & 7 \\
Chronic Cholecystitis & 84 & 59.2
\end{tabular}

\section{Antibiotherapy}

$\begin{array}{lll}\text { Cephazoline } & 59 & 41.5\end{array}$

Cephazoline+

$\begin{array}{lll}\text { metronidazole } & 74 & 52.1\end{array}$

Other (tigecycline, etc) $\quad 9 \quad 6.3$

$\begin{array}{lll}\text { Complications } & 10 & 7.0\end{array}$

Surgical site infections $\quad 5 \quad 3.5$

$\begin{array}{lll}\text { Pulmonary infection } & 3 & 2.1\end{array}$

$\begin{array}{lll}\text { Evisceration } & 1 & 0.7\end{array}$

$\begin{array}{lll}\text { Biliary leakage } & 1 & 0.7\end{array}$

Table 2. Distribution of patients according to definite and suspected diagnosis

\begin{tabular}{|c|c|c|c|}
\hline & $\begin{array}{c}\text { Suspected } \\
\text { diagnosis } \\
\text { (n:58) }\end{array}$ & $\begin{array}{c}\text { Definite } \\
\text { diagnosis } \\
\text { (n: } 84)\end{array}$ & $p$ \\
\hline Age & $51.7 \pm 13.1$ & $51.3 \pm 15.5$ & 0.672 \\
\hline
\end{tabular}

Age group

$\begin{array}{lll}\leq 65 & \text { yrs. } & 49\end{array}$

$>65$ yrs. $\quad 9 \quad 19$

0.204

$\begin{array}{llll}\text { Gender } & & & \\ \text { Female } & 47 & 43 & \\ \text { Male } & 11 & 41 & 0.001\end{array}$

ASA

$\begin{array}{cccc}1 & 15 & 17 & \\ 2 & 42 & 61 & 0.283 \\ 3 & 1 & 6 & \end{array}$

3

Comorbidities

None $\quad 51 \quad 74$

COPD 112

CHF 112

$\begin{array}{lll}\text { DM } & 2 & 4\end{array}$

ESRD 110

Hypertension $\quad 2 \quad 2$

Operation procedure

Open $\quad 30 \quad 64$

$\begin{array}{lll}\text { Laparoscopic } & 24 & 16\end{array}$

0.075

Conversion

$4 \quad 4$

\begin{tabular}{lccc} 
Operation group & & & \\
In 3-5 days & 45 & 54 & \\
In 5-7 days & 13 & 30 & 0.090 \\
Time of operation & $4.4 \pm 1.2$ & $6.8 \pm 1.4$ & 0.356 \\
Complications & & & \\
\hline
\end{tabular}

Surgical site infection $\quad 0 \quad 5$

$\begin{array}{lll}\text { Pulmonary infection } & 2 & 1\end{array}$

0.120

Incisional hernia

Biliary leakage

$\begin{array}{ll}0 & 1 \\ 0 & 1\end{array}$

Grade (according to TG 13)

Grade 1

Grade 2

Grade 3

Pathology evaluation

Acute cholecystitis

Phlegmonous Ch

Gangrenous Ch

Chronic Ch

Antibiotherapy

Cephazoline

Cephazoline+metronidazole others

\begin{tabular}{|lccc|}
\hline Post-op stay & $2.9 \pm 1.3$ & $3.6 \pm 2.1$ & 0.047 \\
\hline $\begin{array}{l}\text { Post-op hospital stay group } \\
\text { 1-4 days }\end{array}$ & 48 & 64 & \\
5-7 days & 10 & 16 & \\
More than 8 days & 0 & 4 & 0.222 \\
\hline Total hospital stay & $7.4 \pm 2.0$ & $8.4 \pm 2.8$ & 0.029 \\
\hline $\begin{array}{l}\text { ASA Score: American Society of Anesthesiologiss score; TG 13: Tokyo guideline } \\
\text { 2013; Ch: cholecystitis; COPD: chronic obstructive pulmonary disease; CHF: } \\
\text { chronic heart failure; DM: diabetes mellitus; ESRD: end stage renal disease }\end{array}$
\end{tabular}


Table 3. Distribution of patients according to Tokyo guideline severity grade

\begin{tabular}{|c|c|c|c|c|}
\hline & \multicolumn{4}{|c|}{ According to Tokyo 2103 Guideline } \\
\hline & $\begin{array}{l}\text { Grade } 1 \\
\text { (n: 106) }\end{array}$ & $\begin{array}{c}\text { Grade } 2 \\
\text { (n:31) }\end{array}$ & $\begin{array}{c}\text { Grade } 3 \\
(n: 5)\end{array}$ & p \\
\hline Age (yrs.) \% (n) & $49 \pm 15$ & $55 \pm 14$ & $63 \pm 8$ & 0.493 \\
\hline Age group \% (n) & & & & 0.283 \\
\hline$\leq 65 \mathrm{yrs}$ & $62(88)$ & $16(23)$ & $2(3)$ & \\
\hline$>65$ yrs. & $13(18)$ & $6(8)$ & $1(2)$ & \\
\hline Gender \% (n) & & & & 0.024 \\
\hline Female & $52(74)$ & $10(14)$ & $1(2)$ & \\
\hline Male & $23(32)$ & $12(17)$ & $2(3)$ & \\
\hline ASA \% (n) & & & & 0.042 \\
\hline 1 & $18(26)$ & $4(6)$ & $0(0)$ & \\
\hline 2 & $55(78)$ & $15(21)$ & $3(4)$ & \\
\hline 3 & $1(2)$ & $3(4)$ & $1(1)$ & \\
\hline Comorbidities \% (n) & & & & 0.208 \\
\hline None & $68(96)$ & $18(26)$ & $2(3)$ & \\
\hline COPD & $0.7(1)$ & $0.7(1)$ & $0.7(1)$ & \\
\hline $\mathrm{CHF}$ & $1.4(2)$ & $0.7(1)$ & $0(0)$ & \\
\hline DM & $2.8(4)$ & $0.7(1)$ & $0.7(1)$ & \\
\hline ESRD & $0.7(1)$ & $0(0)$ & $0(0)$ & \\
\hline
\end{tabular}

Diagnosis (According to TG 13) \% (n)

0.001

\begin{tabular}{lcccc} 
Suspected & $41(58)$ & $0(0)$ & $0(0)$ & \\
Definite & $34(48)$ & $22(31)$ & $3.5(5)$ & \\
Time of Operation (days) \% (n) & $4.4 \pm 1.3$ & $5.3 \pm 1.4$ & $5.8 \pm 1.6$ & 0.004 \\
Surgical procedure \% (n) & & & & 0.014 \\
Open & $37(53)$ & $14(20)$ & $2(3)$ & \\
Laparoscopic & $30(42)$ & $2(3)$ & $1.4(2)$ & \\
Conversion & $8(11)$ & $6(8)$ & $0(0)$ & \\
Operation group \% (n) & & & & 0.001 \\
3-5 days & $58(83)$ & $10(14)$ & $1.4(2)$ & \\
5-7 days & $16(23)$ & $12(17)$ & $2(3)$ & \\
Antibiotherapy \% (n) & & & & 0.191 \\
Cephazoline & $33(47)$ & $8(12)$ & $0(0)$ & \\
Cephazoline+Metronidazole & $36(51)$ & $13(18)$ & $3.5(5)$ & \\
Others (Tigecycline, etc.) & $6(8)$ & $0.7(1)$ & $0(0)$ & \\
Complications \% (n) & & & & 0.392 \\
Surgical site infection & $2(3)$ & $0.7(1)$ & $0.7(1)$ & \\
Lung infection & $2(3)$ & $0(0)$ & $0(0)$ & \\
Incisional hernia & $0(0)$ & $0.7(1)$ & $0(0)$ & \\
Biliary leakage & $0.7(1)$ & $0(0)$ & $0(0)$ & \\
Postop stay (days) \% (n) & $3.0 \pm 1.7$ & $4.0 \pm 1.7$ & $5.2 \pm 3.3$ & 0.014 \\
Postop hospital stay group \% (n) & & & 0.007 \\
1-4 days & $63(90)$ & $13(19)$ & $2(3)$ & \\
5-7 days & $10(14)$ & $8(11)$ & $0.7(1)$ & \\
Over 8 days & $1.4(2)$ & $0.7(1)$ & $0.7(1)$ & \\
\hline Totalhospital stay (days) \% (n) & $7.4 \pm 2.4$ & $9.3 \pm 2.2$ & $11.0 \pm 2.6$ & 0.001
\end{tabular}

Total hospital stay (days) \% (n) $\quad 7.4 \pm 2.4 \quad 9.3 \pm 2.2 \quad 11.0 \pm 2.6 \quad 0.001$

\begin{tabular}{lcccc} 
Pathology evaluation \% (n) & & & \multicolumn{2}{c}{0.001} \\
Acute cholecystitis & $20(28)$ & $10(14)$ & $0(0)$ & \\
Phlegmonous cholecystitis & $0(0)$ & $3.5(5)$ & $0.7(1)$ \\
Gangrenous cholecystitis & $0(0)$ & $6(9)$ & $0.7(1)$ \\
Chronic cholecystitis & $55(78)$ & $2(3)$ & $2(3)$
\end{tabular}

ASA: American Society of Anesthesiologists; TG 13: Tokyo guideline 2013; COPD: chronic obstructive pulmonary disease; CHF: chronic heart failure; DM: diabetes mellitus; ESRD: end stage renal disease
Table 4. Patient length of hospital stay according to surgical procedures

\begin{tabular}{|lcccc|}
\hline & $\begin{array}{c}\text { Open } \\
\text { cholecystectomy }\end{array}$ & $\begin{array}{c}\text { Conversion } \\
\text { group }\end{array}$ & $\begin{array}{c}\text { Laparoscopic } \\
\text { cholecystectomy }\end{array}$ & p \\
\hline $\begin{array}{l}\text { Postoperative } \\
\text { stay (days) }\end{array}$ & $3.7 \pm 1.5$ & $3.8 \pm 1.8$ & $2.6 \pm 2.1$ & 0.001 \\
\hline $\begin{array}{l}\text { Discharge } \\
\text { in 1-4 days (\%) }\end{array}$ & 71 & 79 & 91 & 0.020 \\
\hline $\begin{array}{l}\text { Total hospital } \\
\text { stay (days) }\end{array}$ & $8.6 \pm 2.3$ & $8.5 \pm 2.1$ & $6.8 \pm 2.7$ & 0.001 \\
\hline
\end{tabular}

In this study, no mortality was observed. There were no biliary complications in the open cholecystectomy group, while only one patient developed a biliary complication that was managed with medical treatment in the laparoscopic cholecystectomy group. The rate of postoperative local and general complications was $5 \%$ and $2 \%$, respectively. Surgical operation was performed after a median of 4 days after hospital admission. There was no statistically significant correlation between time to operation and complications. Although length of hospital stay was higher in patients with complications, it was not statistically significant. Analysis of the factors associated with complications revealed histological diagnosis alone as a risk factor. Surgical site infection was more frequent in case of acute cholecystitis, while pulmonary complications were more frequent in patients with chronic cholecystitis. Conversion rate from laparoscopy to open surgery was determined as $13.4 \%$. In multivariate analysis, only histological diagnosis (acute cholecystitis) was found as a risk factor to conversion (OR 0.19; 95\% Cl 0.07-0.41, p:0. 016).

Preoperative length of hospital stay was significantly higher in patients older than 65 years, those with high severity grades, and those who received combination antibiotherapy. ASA score, operation type, gender, diagnosis group, histologic diagnosis and presence of comorbidities or complications were not associated with preoperative length of hospital stay. On multivariate analysis, age older than 65 years (OR $4.21 ; 95 \% \mathrm{Cl}$ 3.53-4.90, p: 0.007), grade 3 disease (OR 5.20; 95\% Cl 1.04-9.36, p: 0.005$)$, and combination antibiotherapy (OR $3.59 ; 95 \% \mathrm{Cl}$ 3.17-4.01, p:0.003) were identified as independent risk factors for preoperative length of hospital stay.

Postoperative length of hospital stay was longer in the open cholecystectomy group as compared to the laparoscopic group. The rate of patients discharged in 1-4 days were $71 \%$ in the open group, $79 \%$ in the conversion group and $91 \%$ in the laparoscopic cholecystectomy group. Table 4 displays the differences between postoperative and total length of hospital stay according to surgical procedures.

Allocation of patients into groups according to preoperative duration of medical treatment (3-5days vs. 6-7 days) showed that while the conversion rate was higher in the 3-5 days group; patients older than 65 years, those with high grade disease $(1.2 \pm 0.4,1.5 \pm 0.6, p: 0.001)$, those who have received combination antibiotherapy, and those with longer postoperative length of hospital stay $(3 \pm 2,3.8 \pm 1.5, \mathrm{p}: 0.045)$ were more frequent in the 6-7 days group. There was no statistically significant difference between the two groups with regard to age, 
gender, ASA score, presence of comorbidities, complication rates, diagnosis according to TG 2013, and histologic diagnosis. On multivariate analysis, older age (OR 5.36; 95\%Cl 4.725.99, p:0.003), surgical procedure (conversion) (RO 4.68;95\%Cl 4.06-5.31, p:0.048), grade 3 disease (OR 5.80; 95\% Cl 3.76-9.84, p:0.001) and combination antibiotherapy (RO 5.11; 95\%Cl 4.76-5.45, p:0.002) were identified as factors related to duration on medical treatment in the preoperative period.

When the patients were further categorized according to preoperative time on medical treatment as those with 3 days or more than 3 days, no correlation was found with regard to age, gender, ASA score, surgical procedure, age group, antibiotherapy type, complication rate, diagnosis according to TG 2013, grade, histological diagnosis, postoperative and total length of hospital stay.

Higher ASA score, open cholecystectomy, patients with a definite diagnosis, high grade cholecystitis, patients older than $65 \mathrm{yr}$ and acute, phlegmonous and gangrenous cholecystitis in histology evaluation were associated with longer postoperative hospital stay. On multivariate analysis, only old age (OR 4.21; 95\%Cl 3.53-4.90, p:0.001) and grade 3 disease (OR $5.20 .95 \% \mathrm{Cl}$ 1.04-9.36, p:0.001) were identified as independent risk factors for longer postoperative hospital stay. (ASA score p:0.093, operation type p:0. 099, histologic diagnosis p:0.485, clinical diagnosis p:0.529). There was no correlation between postoperative hospital stay and gender, age, co-morbidities, complications and antibiotherapy.

Total length of hospital stay was longer in patients with older age, those older than $65 \mathrm{yr}$, those who received combined antibiotherapy, with histologic diagnosis of acute, gangrenous or phlegmonous cholecystitis, and who underwent open cholecystectomy. On multivariate analysis; age (OR 10; 95\%Cl 7.5212.48, p:0.001), older age group (OR 9.64; 95\%Cl 8.77-10.51, p:0.001), combination antibiotherapy (OR 8.72; 95\% Cl 8.149.30, p:0.015) and grade 3 disease (OR 11.0; 95\%Cl 7.71-14.29, p:0.001) was related to longer total length of hospital stay. ASA score, gender, presence of co-morbidities or complications, and TG diagnosis ( $\mathrm{d}$ no affect on total length of hospital stay.

\section{DISCUSSION}

In the 1990's, laparoscopic cholecystectomy was not indicated in patients with acute cholecystitis, open cholecystectomy was routinely performed in such circumstances (19). Interval cholecystectomy (performed 6-8 weeks after medical treatment) was suggested by some centers. Many multicenter randomized controlled trials demonstrated that early laparoscopic cholecystectomy yielded similar mortality, morbidity and conversion rates as compared to interval cholecystectomy (20-23). Recently, early laparoscopic cholecystectomy is suggested as the first line treatment in acute cholecystitis (11). Unfortunately, the rate of early cholecystectomy in patients with acute cholecystitis still remains low (15-40\%) (14-16). In our hospital, the most preferred clinical application is interval cholecystectomy, except our group.

The mortality rate in early laparoscopic cholecystectomy was previously reported as $0.3-0.46 \%(24,25)$. In the present study, no mortality or biliary tract injury was observed in the early open and laparoscopic cholecystectomy groups.
The rate of conversion from laparoscopic to open cholecystectomy was reported as 9.9-31\% (24-29). The conversion rate in the present study was comparable with the literature (13.4\%). The risk factors for conversion were previously defined as presence of symptoms longer than $72 \mathrm{hr}$ and high $C$ reactive protein levels ( $>11.5$ ) (28). In contrast, it has also been reported that duration of symptoms did not influence the rate of conversion (30). Time to surgery was not identified as a risk factor for conversion in the present study. Only the histologic diagnosis of acute cholecystitis was found as a risk factor for conversion.

The studies evaluating complications of early laparoscopic cholecystectomy reported the rate of biliary tract injuries as $0.2-3.5 \%(10,29)$. In the present study, intraoperative biliary tract injury was not observed. The rate of local complications (wound infection, hemorrhage, abscess etc.) and local-systemic complication rates are reported as $4.5 \%$ and $9-20.7 \%(10,26,28,29)$. Comparable with the literature, the local and systemic complication rates in our study were determined as $5 \%$ and $2 \%$, respectively. The only risk factor for developing local and systemic complications was histologic diagnosis of gangrenous cholecystitis. There was no correlation between the severity index according to Tokyo guideline and complications. Navez et al. (29) defined CBD migration and conversion as a risk factor for local complications, and ASA score and histological diagnosis of gangrenous cholecystitis was presented as a risk factor for systemic complications.

Not every patient with acute cholecystitis is suitable to undergo early laparoscopic cholecystectomy, severity assessment of acute cholecystitis should be taken into account while making this decision (11). Cehng et al. (31) reported that surgeons use the Tokyo severity index and Charlson comorbidity score when making the decision to perform early cholecystectomy. The rate of open and laparoscopic cholecystectomy in the early period varies among centers in the literature. In a multicenter study conducted in Belgium, the rate of open cholecystectomy was reported as $6.8 \%$ (29). Also, in a cohort study including 30.000 patients with acute cholecystitis aged older than $65 \mathrm{yr}$, the rate of open cholecystectomy was stated as $29 \%$ (32). In the present study, almost fifty percent of the patients underwent open cholecystectomy. Most of the open cholecystectomy operations were performed in the initial period of our routine early cholecystectomy experiences.

Tokyo guidelines for the management of acute cholecystitis and cholangitis were firstly described in 2007 (17). By the revision committee, these guidelines were improved by means of diagnosis and severity grading in 2013. Criteria for severity grading were adopted in clinical practice $(11,17)$. The diagnostic sensitivity rate was improved from $82.8 \%$ to $91.8 \%$. The false positivity rate was reduced from $15.5 \%$ to $5.9 \%$ (17). In a study including 103 patients with acute cholecystitis who underwent early cholecystectomy, only $71.8 \%$ of the patients matched the diagnosis criteria (31). The sensitivity and validity of the Tokyo guidelines in the Turkish population has not been previously reported. In the present study, the rate of the patients matching the diagnosis criteria according to TG 13 was $59.2 \%$. All patients with a definite diagnosis 
were histologically reported as acute cholecystitis, while all patients with suspected diagnosis except one were (98\%) in the chronic cholecystitis group. These data suggest that diagnostic criteria in TG 13 maybe applied in the Turkish population. Further multicenter studies are needed to validate these results.

Lee et al. (33) suggested that Tokyo guidelines are not useful in clinical practice for prediction of complications and mortality. In contrast, Cheng et al. (31) reported that length of hospital stay and complication rates correlated with Tokyo severity grading system. In addition to the Tokyo severity grading system, the Charlson's comorbidity score has an impact on clinical outcomes in patients with acute cholecystitis (31). In the present study, longer total hospital stay was observed in patients with high severity grade, but there was no correlation between morbidity and severity grade. These findings maybe attributed to the limited number of patients with grade 2 and 3 disease.

The length of hospital stay was previously reported to be longer in the open cholecystectomy group as compared to laparoscopic cholecystectomy, and in the conversion group as compared to the laparoscopy group (29). In a meta-analysis evaluating the clinical safety and results of early and late cholecystectomy, median length of hospital stay was reported as 5.4 days for early laparoscopic cholecystectomy (10). In the present study, median total hospital stay was 6.8 days. In another study comparing laparoscopic cholecystectomies in 72 $\mathrm{hr}$ and after $72 \mathrm{hr}$, postoperative hospital stay was found to be similar among the two groups (26). In this study, postoperative length of hospital stay in the group with laparoscopic cholecystectomy after $72 \mathrm{hrs}$. was determined as $2.4 \pm 1.3$ days. Comparable with the literature, this period was $2.6 \pm 2$ days in the present study.

\section{CONCLUSION}

Increased severity index prolongs pre- and post-operative length of hospital stay. Early cholecystectomy in acute cholecystitis performed by experienced surgeons after 72 hours of admission and within 7 days maybe a feasible and safe procedure.

Ethics Committee Approval: Ethics committee approval was received for this study from the local ethic committee of Tepecik Training and Research Hospital.

Informed Consent: Informed consent was not received due to the retrospective nature of the study.

Peer-review: Externally peer-reviewed.

Author Contributions: Concept - I.S.; Design - I.S., Ö.Ç.; Supervision I.S., F.I.; Data Collection and/or Processing - I.S., M.K., Ö.E.; Analysis and/ or Interpretation - I.S., Ö.Ç.; Literature Search - I.S., M.K., Ö.E.; Writing Manuscript - I.S., Ö.Ç.; Critical Reviews - I.S., F.I.

Conflict of Interest: No conflict of interest was declared by the authors.

Financial Disclosure: The authors declared that this study has received no financial support.

\section{REFERENCES}

1. Shaffer EA. Gallstone disease: Epidemiology of gallbladder stone disease. Best Pract Res Clin Gastroenterol 2006; 20: 981-996. [CrossRef]

2. Duncan $C B$, Riall TS. Evidence-based current surgical practice: calculous gallbladder disease. J Gastrointest Surg 2012; 16: 2011 2025. [CrossRef]

3. Halldestam I, Enell EL, Kullman E, Borch K. Development of symptoms and complications in individuals with asymptomic gallstones. Br J Surg 2004; 91: 734-738. [CrossRef]

4. Kolla SB, Aggarwal S, Kumar A, Kumar R, Chumber S, Pashad R, et al. Early vs delayed laparoscopic cholecystectomy for acute cholecystitis: a prospective randomized trial. Surg Endoscopy 2004; 7: 1323-1327. [CrossRef]

5. Johansson M, Thune A, Blomqvist A, Nelvin L, Lundell L. Management of acute cholecystitis in the laparoscopic era: results of a prospective, randomized clinical trial. J Gastrointest Surg 2003; 7 : 642-645. [CrossRef]

6. Lai PB, Kwong KH, .Leung KL, Kwok SP, Chan AC, Chung SC, et al. Randomized trial of early versus delayed laparoscopic cholecystectomyfor acute cholecystitis. Br J Surg. 1998; 4: 461-467.

7. Siddiqui T, MacDonald A, Chong PS, Jenkins JT. Early versus delayed laparoscopic cholecystectomy for acute cholecystitis: a meta-analysis of randomized clinical trials. Am J Surg 2008; 1: 4047. [CrossRef]

8. Gurusamy KS, Davidson C, Gluud C, Davidson BR. Early versus delayed laparoscopic cholecystectomy for people with acute cholecystittis. Cochrane Database Syst Rev 2013; 30: CD005440.

9. Zhou MW, Gu XD, Xiang JB, Chen ZY. Comparison of Clinical Safety and Outcomes of Early versus Delayed Laproscopic Cholecystectomy for Acute Cholecystitis: A Meta-analysis. Scient World J 2014; 274516.

10. Yamashita Y, Takada T, Strasberg SM, Pitt HA, Gouma DJ, Garden OJ, et al. TG13 surgical management of acute cholecystitis. J Hepatobiliary Pancreat Sci 2013; 20: 89-96. [CrossRef]

11. Al-Mulhim AA. Timing of early laparoscopic cholecystectomy for acute cholecystitis. JSLS 2008; 12: 282-287.

12. Gutt CN, Encke J, Köninger J, Harnoss JC, Weigand K, Kipfmüller $\mathrm{K}$, et al. Acute cholecystitis: early versus delayed cholecystectomy, a multicenter randomized trial. Ann Surg 2013; 3: 385-393. [CrossRef]

13. Agresta F, Ansaloni L,Baiocchi GL, Bergamini C, Campanile FC, Carlucci M, et al. Laparoscopc approach to acute abdomen from the consensus development conference of the Society Italiana di Chirurghi Endoscopica a nouve technologie(SICE), Associazione Chirurghia Ospedalieri Italiani(ACOI), Societa Italıana di Chirurgia (SIC), Societa Italıana di Chiurgiad'Urgenza e del Trauma (SICUT), Societa Italiana di Chirurgia nell'Ospedalita Privata (SICOP), and the European Association for Endoskopic Surgery(EAES). Surg Endosc 2012; 26: 2134-2164. [CrossRef]

14. Casillas RA, Yeniyants S, Collins JC. Early laparoscopic cholecystectomy is the preferred management ofacute cholecystitis. Arch Surg 2008; 143: 533-537. [CrossRef]

15. Cameron IC, Chadwick C, Philips J, Johnson AG. Management of acute cholecystitis in UK hospitals: time for a change. Postgrad Med J 2004; 80: 292-294. [CrossRef]

16. Senapati PS, Bhattarcharya D, Harinath G, Ammori BJ. A survey of the timing and approach to the surgical management of cholelithiasis in the UK. Ann R Coll Surg Engl 2003; 85: 306-312. [CrossRef]

17. Mayumi T, Someya K, Ooutubo H, Takama T, Kıdo T, Kamezaki F, et al. Progression of Tokyo guidelines and Japanese Guidelines for Management of Acute Cholangitis and Cholecystitis. J UOEH 2013; 35: 249-257. [CrossRef]

18. Yokoe M, Takada T, Strasberg SM, et al. New diagnostic criateria and severity assesment of acute cholecystitis: Tokyo guidelines. J Hepatobiliary Pancreat Sci 2012; 19: 578-585. [CrossRef] 
Sert et al.

Early cholecystectomy for acute cholecystitis

19. Cushieri A, Dubois F, Mouiel J, Mouiel P, Becker H, Buess G, et al. The European experience with laparoscopic cholecystectomy. Am J Surg 1991; 161: 385-387. [CrossRef]

20. Gutt C.N, Encke J, Köninger J, Harnoss J.C, Weigand K, Kipfmüller K, et al. Acute Cholecystitis, Early versus delayed cholecystectomy, A multicenter Randomized Trial. Ann Surg 2013; 3: 385-393. [CrossRef]

21. Germanos S, Gourgiotis S, Kocher HM. Clinical update: early surgery for acute cholecystitis. Lancet 2007; 369: 1774-1776. [CrossRef]

22. Lau H, Lo CY, Patil NG, Yuen WK. Early versus delayed-interval laparoscopic cholecystectomy for acute cholecystitis: a metaanalysis. Surg Endosc 2006; 20: 82-87. [CrossRef]

23. Siddiqui T, MacDonal A, Chong PS, Jenkins JT. Early versus delayed laparoscopic cholecystectomy for acute cholecystitis: a metaanalysis of randomized clinical trials. Am J Surg 2008; 195: 40-47. [CrossRef]

24. Hartwig W, Büchler MW. Acute Cholecystitis, Early versus delayed surgery. Adv Surg 2014; 48: 155-164. [CrossRef]

25. Mestral C, Rotstein O, Laupacis A,Hoch JS, Zagorski B, Alali A.S, Nathens A.B. Comparative operative outcomes of early and delayed cholecystectomy for acute cholecystitis. Ann Surg 2014; 1: 10-15. [CrossRef]

26. Oymaci E, Ucar AD, Yakan S, Carti EB, Coskun A, Erkan N. Determination of optimal operation timefor the management of acute cholecystitis: a clinical trial. Prz Gastroenterol 2014; 9: 147-152. [CrossRef]

27. Johansson M, Thune A, Blomqvist A, Nelvin L, Lundell L. Management of acute cholecystitis in the laparoscopic era: result of a prospective randomized clinical trial. J Gastrointest Surg 2003; 7: 642-645. [CrossRef]

28. Asai K, Watanabe M, Kusachi S, Matsukiyo H, Saito T, Kodama H, et al. Risk factors for conversion of laparoscopic cholecystectomy to open surgery associated with the severity characteristics according to the Tokyo guidelines. Surg Today 2014; 44: 2300-2304. [CrossRef]

29. Navez B, Ungureanu F, Michiels M, Claeys D, Muysoms F, Hubert $C$, et al. Surgical management of acute cholecystitis: results of a 2-year prospective multicenter survey in Belgium 2012; 26: 24362445.

30. Gomes RM, Mehta NT, Varik V, Doctor NH. No 72-hour pathological boundary for safe early laparoscopic cholecystectomy in acute cholecystitis: a clinicipathological study. Ann Gastroent 2103; 26: 340-345.

31. Cheng WC, Chiu YC, Chunang CH, Chen CY. Assessing clinical outcomes of patients with acute calculous cholecystitis in addition to the Tokyo grading: A retrospective study Kaohsiung J Med Sciences 2014; 30: 459-465. [CrossRef]

32. Riall TS, Zhang D, Townsend CM Jr, Young FK, Goodwin JS. Failure to perform cholecystectomy for acute cholecystitis in elderly patients is associated with increased morbidity, mortality and cost. J Am Coll Surg 2010; 210: 668-679. [CrossRef]

33. Lee SW, Yang SS, Chang CS, Yeh HJ. Impact of the Tokyo guidelines on the management of patients with acute calculous cholecystitis. J Gastroenterol Hepatol 2009; 24: 1857-1861.[CrossRef] 